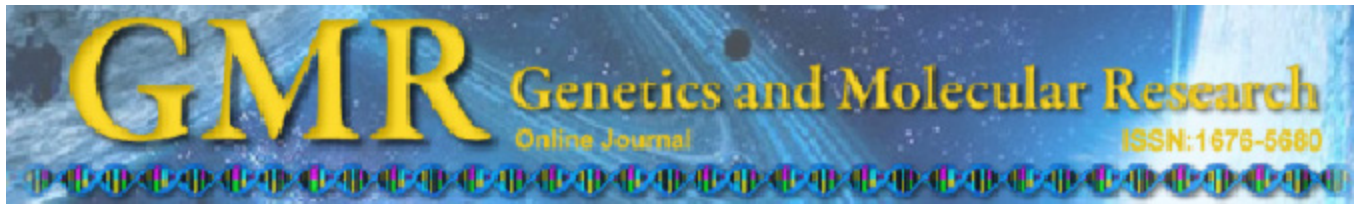

\title{
Antigenotoxic and antimutagenic effects of glutamine supplementation on mice treated with cisplatin
}

\author{
J.R. Pesarini ${ }^{1,2}$, S.G. Victorelli ${ }^{3}$, A.P. Vicentini ${ }^{4}$, L.K. Ferreira ${ }^{4}$, \\ M.O. Mauro ${ }^{1,5}$, R. Matuo ${ }^{1,6}$, J.R. Oliveira ${ }^{1,2}$, A.C.M.B. Antoniolli ${ }^{1,2}$, \\ M.S. Mantovani ${ }^{7}$ and R.J. Oliveira ${ }^{1,2,6}$ \\ ${ }^{1}$ Centro de Estudos em Células Tronco, Terapia Celular e Genética Toxicológica, \\ Núcleo de Hospital Universitário, Universidade Federal de Mato Grosso do Sul, \\ Campo Grande, MS, Brasil \\ ${ }^{2}$ Programa de Pós-Graduação em Saúde e Desenvolvimento na Região \\ Centro-Oeste, Faculdade de Medicina "Dr. Hélio Mandetta", \\ Universidade Federal de Mato Grosso do Sul, Campo Grande, MS, Brasil \\ ${ }^{3}$ School of Biological Sciences, Royal Holloway University of London, \\ Egham, Surrey, United Kingdom \\ ${ }^{4}$ Centro de Estudos em Nutrição e Genética Toxicológica, \\ Centro Universitário Filadélfia, Londrina, PR, Brasil \\ ${ }^{5}$ Programa de Doutorado em Biotecnologia e Biodiversidade - Rede Pró \\ Centro-Oeste, Universidade Federal de Mato Grosso do Sul, \\ Campo Grande, MS, Brasil \\ ${ }^{6}$ Programa de Mestrado em Farmácia, Centro de Ciências Biológicas e da Saúde, \\ Universidade Federal de Mato Grosso do Sul, Campo Grande, MS, Brasil \\ ${ }^{7}$ Departamento de Biologia Geral, Centro de Ciências Biológicas, \\ Universidade Estadual de Londrina, Londrina, PR, Brasil \\ Corresponding author: R.J. Oliveira \\ E-mail: rodrigo.oliveira@ufms.br
}

Genet. Mol. Res. 13 (3): 4820-4830 (2014)

Received December 11, 2013

Accepted March 28, 2014

Published July 2, 2014

DOI http://dx.doi.org/10.4238/2014.July.2.11

ABSTRACT. We evaluated the effects of glutamine on clastogenic and genotoxic damage prevention caused by the administration of cisplatin. 
Forty Swiss mice were divided into 8 experimental groups: $\mathrm{G} 1$ and G2, which were control groups; G3, G4, and G5, which were administered [2 doses of glutamine (orally)] separated by a $24-\mathrm{h}$ period $(150,300$, and $600 \mathrm{mg} / \mathrm{kg}$, respectively), and a dose of phosphate-buffered saline by intraperitoneal injection; G6, G7, and G8, which were treated in the same manner as the previous groups, but received cisplatin rather than phosphate-buffered saline. The antimutagenicity groups showed damage reduction percentages of $79.05,80.00$, and $94.27 \%$ at the time point $\mathrm{T} 1,53.18,67.05$, and 64.74 at time point $\mathrm{T} 2$ for the 150,300 , and $600 \mathrm{mg} / \mathrm{kg}$ doses of glutamine, respectively. Antigenotoxic activity was evident for all 3 doses with damage reduction percentages of 115.05, 119.06 , and 114.38 for the doses of glutamine of 150,300 , and $600 \mathrm{mg} /$ $\mathrm{kg}$, respectively. These results suggest that further studies are needed to confirm the clastogenic activity of glutamine. However, our results may lead to rational strategies for supplementation of this antioxidant as an adjuvant in cancer treatment or for preventing genomic lesions.

Key words: Antioxidant; Cancer treatment; Chemoprevention

\section{INTRODUCTION}

Cancer is a disease characterized by genetic changes that alter the control of cell division and give autonomy to cells to invade other organic structures (Carvalho, 2000). Initiation of cancer may be associated with changes in DNA induced by exposure to a carcinogenic agent (Garófolo et al., 2004). These changes may be classified as either genotoxic or clastogenic (Camargo et al., 1994) and can be measured using assays such as the comet and micronucleus assays (Ribeiro et al., 2003).

Development of the most common forms of cancer results from interactions between endogenous and environmental factors, most notably food intake. Approximately $35 \%$ of various types of cancer are thought to be related to an inadequate diet (Garófolo et al., 2004). Thus, dietary components that can reduce the risk of genotoxic or mutagenic events may be indirectly associated with cancer prevention by reducing the risk of cell initiation leading to neoplasm development (Oliveira et al., 2006, 2007, 2009). Various dietary factors are associated with cancer prevention. These factors vary from traditional nutrients such as vitamins, antioxidants, and vegetable polysaccharides found in foods such as greens, vegetables, meats, fruits, and phytochemicals, including glucosinolates, phytoestrogens, and carotenoids (Sies, 1993).

The philosophy that food can be a health promoter, in addition to having nutritional value, has attracted the attention of the public and the scientific community, as diet was shown to be linked to disease prevention and treatment. Functional foods are defined as biologically active food items, which provide health or clinical benefits (Krause and Mahan, 2005).

Phytochemicals, for example, have been studied for their role in the prevention and treatment of chronic disease, particularly cancer, because plant-based foods can inactivate or eliminate carcinogenic or mutagenic drugs. These detoxification activities have overlapping and complementary mechanisms that include the neutralization of free radicals as well as the activation of enzymes that eliminate carcinogens (Potter and Steinmetz, 1996). 
Phytochemicals can act as blocking agents or suppressors to reduce the risk of cancer by preventing carcinogen activity or access to target tissue through several modes of action. Possible modes of action include induction of enzyme systems that detox the carcinogens, capture and arrest of reactive carcinogens, and blockage of cellular events necessary for tumor promotion. Suppressor agents, whose actions are less well-defined, can prevent carcinogenesis by acting at a cellular level, preventing malignant expression in cells exposed to causative agents of cancer (Wattenberg, 1992). Thus, other natural or synthetic products, such as those used in food, have been examined for their ability to prevent changes in DNA. Immunonutrition studies indicate that not only nutritional status improvement is possible, but also a role for functional foods in immune function and response to cancer treatment (Waitzberg, 2000). Various studies have been conducted involving glutamine, which appeared to enhance body antioxidant defenses (Pacífico et al., 2004). Thus, glutamine should be tested in cancer prevention and for use in adjuvant chemotherapy treatment. Glutamine is a neutral, glycogenic, non-essential amino acid; however, it may become indispensable in catabolic situations, such as trauma and sepsis. Thus, various studies indicate that this amino acid is essential. Essential amino acids cannot be synthesized in the body and therefore must be supplied in the diet (Diestel et al., 2005). Based on the results of previous studies, we examined the anticlastogenic activity of glutamine.

\section{MATERIAL AND METHODS}

\section{Chemical agents}

DNA damage was induced using cisplatin (Sigma, St. Louis, MO, USA), at a 6.0 $\mathrm{mg} / \mathrm{kg}$ final dose and prepared in sterile phosphate-buffered saline (PBS), $\mathrm{Mg}^{2+}$ - and $\mathrm{Ca}^{2+}$ free, $\mathrm{pH}$ 7.4. Glutamine was supplied by Droganorte (Londrina/PR, Brazil) by the pharmacist Rosângela Chammé (CRF9-2463). Solutions were prepared in sterile PBS, $\mathrm{Ca}^{2+}$ - and $\mathrm{Mg}^{2+}-$ free, $\mathrm{pH} 7.4$, to prepare doses of 150,300 , and $600 \mathrm{mg} / \mathrm{kg}$ body weight (bw). Doses were previously determined in pilot experiments.

\section{Experimental design}

Male Swiss mice (Mus musculus) under reproductive age were used $(\mathrm{N}=40)$, with an average weight of $30 \mathrm{~g}$, from Biotério Central of Universidade Estadual de Maringá. The experiment was conducted at Biotério de Nutrição Experimental of Centro Universitário Filadelfia (UNIFIL). Animals were kept in isolated metabolic boxes and the minimum period of adjustment was 7 days. The luminosity and temperature were controlled, the photoperiod for

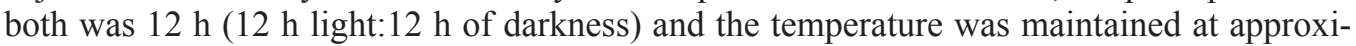
mately $22 \pm 2{ }^{\circ} \mathrm{C}$ with a relative humidity of $55 \%$. Their diet consisted of filtered water and commercial food available ad libitum.

Animals were divided into the following 8 experimental groups $(\mathrm{N}=5)$ : Group 1 (G1): the animals received 2 PBS doses $(0.1 \mathrm{~mL} / 10 \mathrm{~g}$ bw, orally (po) separated by a $24-\mathrm{h}$ period). Immediately after the last PBS dose, the animals received an additional dose of the same solution by intraperitoneal injection (ip).

In Group 2 (G2), the animals received 2 PBS doses $(0.1 \mathrm{~mL} / 10 \mathrm{~g} \mathrm{bw}$, po) separated 
by a $24-\mathrm{h}$ period. Immediately after the last PBS dose, the animals received cisplatin (6 $\mathrm{mg} /$ $\mathrm{kg}$ bw, ip).

In Groups 3, 4, and 5 (G3, G4, and G5): the animals received 2 glutamine doses (po) separated by a $24-\mathrm{h}$ period. Immediately after the last glutamine dose, the animals received a PBS dose $(0.1 \mathrm{~mL} / 10 \mathrm{~g} \mathrm{bw}, \mathrm{ip})$. The glutamine doses were 150,300 , and $600 \mathrm{mg} / \mathrm{kg}$ bw for G3, G4, and G5, respectively.

In Groups 6, 7, and 8 (G6, G7, and G8): the animals received 2 glutamine doses (po) separated by a $24-\mathrm{h}$ period. Immediately after the last glutamine dose, the animals received a cisplatin dose $(6 \mathrm{mg} / \mathrm{kg}$ bw, ip). The glutamine doses were 150,300 , and $600 \mathrm{mg} / \mathrm{kg}$ bw for G6, G7, and G8, respectively.

Peripheral blood was collected from the experimental groups by tail vein puncture at 3 different time points ( $\mathrm{T} 0, \mathrm{~T} 1$, and $\mathrm{T} 2$ ) to evaluate the mutagenicity and antimutagenic effects by the micronucleus assay. $\mathrm{T} 0$ indicates that collection preceded drug administration. $\mathrm{T} 1$ and $\mathrm{T} 2$ refer to the collections at 48 and $72 \mathrm{~h}$, respectively, after the first glutamine administration or vehicle. At $72 \mathrm{~h}$, a peripheral blood sample was collected for the comet assay.

\section{Micronucleus assay}

Various methods exist for evaluating clastogenicity and anticlastogenicity. One of these methods uses the micronucleus in peripheral blood as described by Hayashi et al. (1990), with modifications proposed by Oliveira et al. (2009). A drop of peripheral blood was placed on a previously prepared slide with a layer of $20 \mu \mathrm{L} 1.0 \mathrm{mg} / \mathrm{mL}$ acridine orange. A coverslip was then placed on the slide and the slide was placed into a $-20^{\circ} \mathrm{C}$-freezer for at least $48 \mathrm{~h}$. Analysis of slides was conducted using a fluorescence microscope (UV light $488 \mathrm{~nm}$ ) with a 100X-objective lens. A total of 2000 cells/animal were analyzed and statistically analyzed using the chi-squared test $(\mathrm{P}<0.05)$.

\section{Comet assay}

The comet assay was performed according to the procedure described by Singh et al. (1988) and Tice et al. (2000). To prepare the glass slide, $20 \mu \mathrm{L}$ total blood was added to the slide, collected with $120 \mu \mathrm{L}$ agarose LPM $(1.5 \%)$ at $37^{\circ} \mathrm{C}$ on a pre-covered glass slide with normal agarose (5\%) that was re-covered with a glass coverslip and cooled to $4^{\circ} \mathrm{C}$ for $20 \mathrm{~min}$. After removing the coverslips, the slides were immersed in fresh lysis solution composed of $89 \mathrm{~mL}$ lysis stock solution $(2.5 \mathrm{M} \mathrm{NaCl}, 100 \mathrm{mM}$ EDTA, $10.0 \mathrm{mM}$ Tris, $\mathrm{pH}$ 10, adjusted with solid $\mathrm{NaOH}, 890 \mathrm{~mL}$ distilled water, and 1\% sodium laurylsarcosinate), $1.0 \mathrm{~mL}$ Triton X-100 (Merck, White House Station, NJ, USA), and $10 \mathrm{~mL}$ dimethyl sulfoxide. Cells were lysed for $1 \mathrm{~h}$ at $4^{\circ} \mathrm{C}$ protected from light. Next, the slides were transferred to an electrophoresis chamber containing a $\mathrm{pH}>13.0$ buffer $(300 \mathrm{mM} \mathrm{NaOH}$ and $1 \mathrm{mM}$ EDTA, prepared from a stock solution of $10 \mathrm{~N}$ $\mathrm{NaOH}$ and $200 \mathrm{mM}$ EDTA, $\mathrm{pH} 10.0$ ) at $4^{\circ} \mathrm{C}$ for $20 \mathrm{~min}$ to denature the DNA. Electrophoresis was conducted at $25 \mathrm{~V}$ and $300 \mathrm{~mA}(1.25 \mathrm{~V} / \mathrm{cm})$. Subsequently, the slides were neutralized with $\mathrm{pH} 7.5$ buffer $(0.4 \mathrm{M}$ Tris-HCl) with 3 buffer changes for 5 min, air-dried, fixed in absolute ethanol for $10 \mathrm{~min}$, and stored for later scoring. The slides were stained with $100 \mu \mathrm{L} 20 \mu \mathrm{g} / \mathrm{mL}$ ethidium bromide and then covered with a coverslip. The cells were evaluated using a fluorescence microscope (Nikon, Tokyo, Japan) at 40X magnification using an excitation filter of 420-490 nm 
and barrier filter of $520 \mathrm{~nm}$. A total of 100 cells per treatment were visually inspected. Comets were classified as: class 0 for undamaged cells showing no tail; class 1 for cells with a tail size less than the diameter of the nucleoid; class 2 for cells with a tail size 1-2 times the diameter of the nucleoid; and class 3 for cells with a tail size greater than 2 times the diameter of the nucleoid. Apoptotic cells showing a completely fragmented nucleus were not scored (Kobayashi et al., 1995). The total score was calculated as the sum of the number of cells scored for each class times that class value. Statistical analysis was performed using the Student $t$-test $(\mathrm{P}<0.05)$.

\section{Calculation of damage reduction percentage}

The percent reduction in cisplatin damage (DR\%) related to glutamine supplementation was calculated as follows: [cisplatin group mean - the mean of an associated group (groups 6, 7, or 8)] / (cisplatin group mean - control group mean). The result was multiplied by 100 to obtain the percent reduction. This procedure was performed to evaluate the $\mathrm{DR} \%$ in the comet and micronucleus assays (Waters et al., 1990).

\section{RESULTS}

Table 1 shows the frequency, average, standard deviation, and DR\% determined using the micronucleus test of peripheral blood. Statistical analysis showed that at T0, only the G3 and G4 groups had an increased frequency of basal damage compared to the control group. At T1, G2 showed a significant increase in micronucleus frequency following cisplatin administration. When mutagenicity was evaluated, G3 and G4 showed increased micronucleus frequencies compared to G1 and were the same as the control group at T1. However, in T2, a statistically significant increase was observed for G3 and G5. Thus, only the intermediate dose was not clastogenic. In the antimutagenic assessment, upon comparison of groups G6, G7, and G8 with G2, in T0 all experimental groups showed the same micronucleus frequencies. However, in $\mathrm{T} 1$ there was a statistically significant decrease when the different experimental groups were compared with G2. The DR\% values were $79.05,80.00$, and $94.27 \%$ at $\mathrm{T} 1$ for the 150,300 , and $600 \mathrm{mg} / \mathrm{kg}$ bw glutamine doses, respectively. T2 analysis showed similar results. Thus, all 3 glutamine doses were effective for preventing clastogenic damage induced by cisplatin and the DR\% values of this time point were $53.18,67.05$, and $64.74 \%$.

\begin{tabular}{|c|c|c|c|c|c|c|c|c|}
\hline \multirow[t]{2}{*}{ Treatment } & \multicolumn{3}{|c|}{ Frequency of MN } & \multicolumn{3}{|c|}{ Mean \pm SD } & \multicolumn{2}{|c|}{$\mathrm{DR} \%$} \\
\hline & T0 & $\mathrm{T} 1$ & T2 & T0 & $\mathrm{T} 1$ & T2 & $\mathrm{T} 1$ & T2 \\
\hline Group 1 & 41 & 22 & 20 & $8.20 \pm 1.64$ & $4.40 \pm 0.55$ & $4.00 \pm 1.22$ & - & - \\
\hline Group 2 & $28^{\mathrm{a}}$ & $127^{\mathrm{a} *}$ & $193^{\mathrm{a} *}$ & $5.60 \pm 2.07$ & $25.40 \pm 3.58$ & $38.60 \pm 3.85$ & - & - \\
\hline \multicolumn{9}{|c|}{ Mutagenicity } \\
\hline Group 3 & $67^{\mathrm{a} *}$ & $23^{\mathrm{a}}$ & $45^{\mathrm{a} *}$ & $13.40 \pm 3.51$ & $4.60 \pm 1.34$ & $9.00 \pm 2.34$ & - & - \\
\hline Group 4 & $75^{\text {a* }}$ & $39^{\mathrm{a}}$ & $35^{\mathrm{a}}$ & $15.00 \pm 4.58$ & $7.80 \pm 0.84$ & $7.00 \pm 1.58$ & - & - \\
\hline Group 5 & $48^{\mathrm{a}}$ & $30^{\mathrm{a}}$ & $41^{\mathrm{a} *}$ & $9.60 \pm 1.52$ & $6.00 \pm 1.00$ & $8.20 \pm 1.92$ & - & - \\
\hline \multicolumn{9}{|c|}{ Antimutagenicity } \\
\hline Group 6 & $18^{\mathrm{b}}$ & $44^{\mathrm{b} *}$ & $101^{\mathrm{b} *}$ & $3.60 \pm 1.95$ & $8.80 \pm 1.30$ & $20.20 \pm 4.15$ & 79.05 & 53.18 \\
\hline Group 7 & $32^{\mathrm{b}}$ & $43^{\mathrm{b} *}$ & $77^{\mathrm{b} *}$ & $6.40 \pm 1.82$ & $8.60 \pm 1.52$ & $15.40 \pm 2.07$ & 80.00 & 67.05 \\
\hline Group 8 & $18^{\mathrm{b}}$ & $28^{\mathrm{b} *}$ & $81^{\mathrm{b} *}$ & $3.60 \pm 1.14$ & $5.60 \pm 1.52$ & $16.20 \pm 1.48$ & 94.27 & 64.74 \\
\hline
\end{tabular}

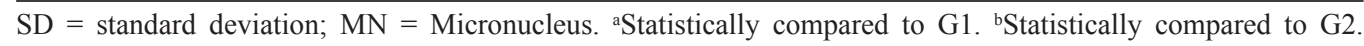
*Significant statistical difference (chi-squared; $\mathrm{P}<0.05$ ). 
Table 2 shows the frequency of injured cells, distribution among damage classes, $\mathrm{DR} \%$ values, and score relating to the comet assay in peripheral blood. Statistical analysis showed that cisplatin was effective for causing genotoxic damage when compared to the damage produced by the control group. In genotoxicity assessment, when animals were treated with glutamine only, DNA damage was not induced. However, there was a statistically significant reduction in basal genotoxic frequency for the intermediate dose, as the average number of cells damaged was $17.20 \pm 8.04$ and $3.40 \pm 2.79$ in the G1 and G4 groups, respectively.

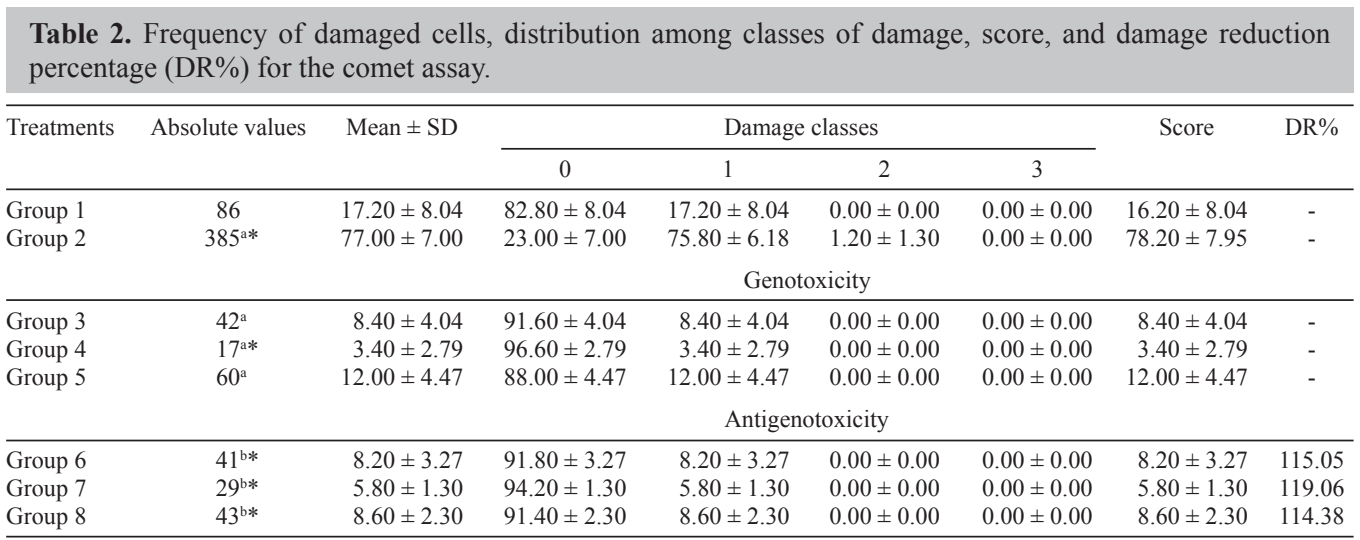

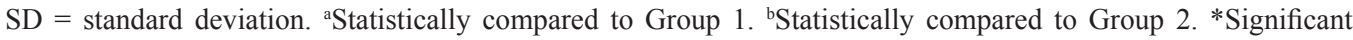
statistical difference (chi-squared; $\mathrm{P}<0.05$ ).

In the examination of antigenotoxicity, when we assessed glutamine activity associated with cisplatin, for all concentrations tested, cisplatin was prevented from causing DNA damage. A dose response curve for the doses used was not determined, and the DR\%s were similar among the different glutamine concentrations, including 115.05, 119.06, and $114.38 \%$ for glutamine doses of 150,300 , and $600 \mathrm{mg} / \mathrm{kg}$ bw, respectively.

\section{DISCUSSION}

Upon examining antigenotoxicity, when we assessed glutamine activity associated with cisplatin, it was found that for all concentrations tested DNA damage caused by cisplatin exposure was prevented. A dose-dependent response was not observed, and the damage reduction percentages were similar among the different glutamine concentrations. This was revealed by the damage reduction percentages of $115.05,119.06$, and $114.38 \%$ for the glutamine doses of 150,300, and $600 \mathrm{mg} / \mathrm{kg}$ bw, respectively. Oliveira et al. (2013) also tested the chemopreventive activity of glutamine using the same assays but with a different protocol. The authors also observed no dose-dependent response, but similar DR\% values were observed for the comet assay.

Human tumor initiation and progression comprise multiple stages and involve the accumulation of genetic changes in somatic cells. These changes consist of the activation of oncogenes and the inactivation of tumor suppressor genes, and it appears that both changes are necessary to cause a neoplastic phenotype (Ojopi and Neto, 2002). 
The large number of chromosomal alterations observed in some tumors associated with the physiological and morphological heterogeneity of individual tumor cells formed the basis of the mutant phenotype concept in cancer. Loeb et al. (1974) suggested that multiple mutations found in tumor cells result from mutations in genes that ensure DNA synthesis fidelity or its repair (Ojopi and Neto, 2002).

DNA damage occurs primarily by chance; when this damage is not repaired, it can be a potential source of mutations. These changes may occur in genes necessary for maintaining genetic stability, potentially causing additional mutations throughout the genome and leading to a cascade of mutations that contribute to cancer development. Moreover, other mutations that arise from lifestyle and dietary habits may also lead to cancer formation (Gold et al., 1997).

Generally, induced and/or basal mutations can be evaluated using different methods. In this study, the micronucleus assay of the peripheral blood described by Hayashi et al. (1990) was used with some modifications.

Previous studies provide evidence of a relationship between nutrition and risk of cancer development. Cancer chemoprevention involves substances that can prevent the neoplasm process from the beginning or stop or reverse the progression of transformed cells into malignant phenotypes (Peres et al., 2003). Thus, preventive strategies may be effective because most malignant neoplasms are related to preventable risk factors, including dietary components (Padilha and Pinheiro, 2005). Experimental and epidemiological data, which indicate a relationship between diet and cancer risk, highlight some components with chemopreventive functions, such as functional foods.

Food not only nourishes the body, but also provides nutrients for appropriate body functioning and preventing diseases. However, functional foods are not intended to cure or treat diseases. Rather, they serve to enhance metabolic or physiological functions that contribute to physical health, as well as reduce the occurrence of chronic diseases. Functional foods should be integrated into the normal diet. Their positive effects should be obtained in nontoxic quantities and will continue even after intake suspension. (Padilha and Pinheiro, 2005).

In this study, cisplatin was used to induce DNA damage. Cisplatin is a complex of heavy metals, containing 2 chlorine atoms and 2 ammonia molecules in the cis position. Cisplatin is considered to be the main representative of a class of potent antineoplastic agents, the coordinated platinum complex. It is effective in antineoplastic chemotherapy when administered via intravenous or intraperitoneal routes. Cisplatin has shown therapeutic potential in a wide variety of human and animal neoplasms. It can react with many cellular structures and molecules, such as membranes, proteins, and RNA, but its specific target is DNA. Administration of antioxidant agents, which can sequester free radicals from oxygen, results in effective protection against the oxidative damage induced by cisplatin (Antunes and Bianchi, 2004).

In glutamine clastogenicity analysis $(150,300$, and $600 \mathrm{mg} / \mathrm{kg})$, supplementation with glutamine at 2 different concentrations increased the micronucleus frequency in animals in the experimental groups at time T2 (G3 and G5). However, the data is contradictory because in G3 and G4, glutamine reduced micronucleus basal levels. Thus, it appears that at time T0, these 2 groups had a high micronucleus frequency, which were reduced to a statistically significant level when reevaluated at time $\mathrm{T} 1$, which was $48 \mathrm{~h}$ after the first glutamine dose administration. During the adjustment period, animals in these experimental groups showed no evidence that their health was effected.

Further studies regarding enteral glutamine supplementation should be conducted to verify its capacity to induce DNA damage. One of the first studies reporting the safety of 
glutamine use in clinical nutrition was conducted by Ziegler et al. (1990). According to their study, the metabolic effectiveness of glutamine in bone marrow transplantation was observed at a dose of $0.57 \mathrm{~g}$ glutamine $/ \mathrm{kg}$ bw/day (Ziegler et al., 1992).

However, the literature suggests the daily use of glutamine as an amino acid in enteral and parenteral nutrition in intestinal dysfunction syndrome cases, short bowel, inflammatory bowel disease, enteritis induced by radio and chemotherapy, infectious enteritis, immunodeficiency states, AIDS, immune system disorders associated with critical states or with bone marrow transplantation, hypercatabolic situations, burns, multiple traumas, large surgeries, septic shock, among others (Albertini and Ruiz, 2001).

Furthermore, when the chemopreventive capacity of glutamine was evaluated at 3 different doses $(150,300$, and $600 \mathrm{mg} / \mathrm{kg})$, this compound was effective for preventing DNA damage. According to statistical analysis, the percentage of harm was reduced, ranging from $79.05-94.27 \%$ in T1 and $53.18-67.05 \%$ in T2. Given this chemopreventive capacity, it can be inferred that when this amino acid is associated with the antineoplastic agent cisplatin, some of the side effects of cisplatin therapy may be reduced. Clastogenic damages were reduced at the different doses used. At T1, the lowest dose was the most effective for reducing micronucleus frequency, with damage reduced by $79.05 \%$.

Generally, increasing the supplementation dose will improve DNA damage prevention. According to Ziegler et al. (1990, 1992), this dose-response curve relationship can be observed during prenatal glutamine supplementation in humans, particularly following bone marrow transplantation. For some supplements, such as $\beta$-glucan, a characteristic dose-response curve is observed at any given time point. According to Angeli et al. (2006), when the chemopreventive effects of $\beta$-glucan were evaluated in vitro upon exposure to damage-induction agents as hydrogen peroxide, 3-amino-1-methyl-5-pyridol[4,3-b]indole-3-carbinol, and methylmethane sulfonate, a dose-response curve was observed for the percentages of DNA damage reduction. However, other studies with supplementation, both in vivo and in vitro, using the same polysaccharide and different inducers of DNA damage (methylmethane sulfonate, 2-amino-anthracene, and cyclophosphamide) did not show similar results (Oliveira et al., $2006,2007,2009)$. In this case, there was no relationship with a dose-response curve. Thus, for supplementation and/or patients' cost-benefit, the lowest dose will have beneficial effects.

At time point $\mathrm{T} 2$, there was a lower percentage of damage reduction for all doses examined. However, at this time point, in contrast to T1, all doses showed very similar chemopreventive activity, which does not justify the use of high supplementary doses to animals and/or patients. The percentages of damage reduction were $53.18,67.05$, and $64.74 \%$ for the doses of 150,300 , and $600 \mathrm{mg} / \mathrm{kg}$, respectively.

Generally, the decreased chemopreventive capacity of glutamine at T1 and T2, (24 and $48 \mathrm{~h}$ after the last glutamine administration) was linked to a plasmatic decrease of this amino acid. Thus, this 24-h interval between the 2 blood samples showed that this period was necessary for the animal body to metabolize glutamine in other pathways. Therefore, a lower amount of this amino acid was available to prevent mutagenic damage caused by cisplatin.

We also evaluated the same 3 concentrations of glutamine to examine genotoxic and/ or antigenotoxic activity. DNA damage was not observed for any doses tested. Thus, glutamine has no genotoxic activity. In addition, the intermediate dose causes a statistically significant reduction of approximately 4.67-fold in basal damage following treatment with a dose of $300 \mathrm{mg} / \mathrm{kg}$ bw. Chemopreventive activity was observed for all doses tested when glutamine was associated with cisplatin. 
Analysis of the frequency of injured cells revealed no dose-response relationship. The percentages of damage reduction were $115.05,119.06$, and $114.38 \%$ for doses of 150,300 , and $600 \mathrm{mg} / \mathrm{kg}$ bw.

In the comparison of genotoxicity with antigenotoxicity, the intermediate dose not only reduced the frequency of basal cell injury, but also was the most effective for preventing damage caused by cisplatin. Interestingly, the percentage of damage reduction was very close to that for the 3 doses tested. Thus, supplementation with high doses is unnecessary. In summary, it can be inferred that supplementation with glutamine is not associated with damage to DNA detectable using the comet assay. Therefore, this food intervention is safe for humans. Based on our data, a possible mode of action for glutamine is related to its antioxidant character. Antioxidant agents make up the largest carcinogenesis inhibitor group because they are free radical blockers (Kelloff et al., 1999; Krause and Mahan, 2005).

Antioxidants are substances that even at low concentrations can delay or inhibit oxidation rates (Sies, 1993; Maxwell, 1995). The most widely used classification for these substances divides antioxidants into 2 systems: enzymatic, composed of enzymes produced in the body, and non-enzymatic, composed of vitamins, flavonoids, lycopene, bilirubin (Sies, 1993), and potentially glutamine.

There are 2 main classes of DNA protective substances, those with desmutagenic mechanisms of action and those with bioantimutagenic mechanisms (Kada et al., 1982). Desmutagenic substances can prevent the action of damage-inducing agents by adsorbing to them. Bioantimutagenic agents can act in injury prevention or DNA repair (Kada and Shimoi, 1987).

To elucidate the mechanisms of action of molecules or chemical compounds in antimutagenicity, it is necessary to use different treatment protocols (Flagg et al., 1995). Because the simple simultaneous treatment protocol reveals not only desmutagenic activity but also bioantimutagenic activity, the simultaneous group with pre-incubation and pretreatment showed desmutagenic activity, while post-treatment indicated bioantimutagenic activity. However, to validate the possible mechanism of action of glutamine, it is necessary to develop different isolated protocols.

Another study indicated that glutamine is an important precursor in glutathione synthesis, which is an endogenous antioxidant, and therefore is effective for preventing injury caused by chemotherapy treatment (Neu et al., 1997). Mora et al. (2003) indicated that pretreatment with glutamine inhibited the rate renal glutathione synthesis, which is induced by cisplatin for over $24 \mathrm{~h}$ after administration. A reduction in nephrotoxicity induced by this drug was observed. The same author also reported that the exact mechanism of action of nephrotoxicity induction of cisplatin is not understood.

Previous studies have provided evidence that chemotherapy side effects are mediated by free radicals both in vivo and in vitro (Antunes and Bianchi, 2004). Weijl et al. (1998) found that chemotherapy with cisplatin reduces the patient's plasma antioxidant levels, demonstrating that free radical production occurs during treatment. Antioxidant administration does not appear to interfere in the antitumor effect of antineoplastics as these drugs destroy cancer cells through other mechanisms that do not involve the action of free radicals.

Therefore, antioxidants in the diet may act as chemoprotectors, preventing against the side effects induced by free radicals and the development of secondary cancer related to DNA mutations induced by oxidative stress (Elsendoorn et al., 2001).

The benefits of lifestyle changes, including diet changes, in reducing the global incidence and mortality rates of cancer have been widely documented. Adopting healthy habits, 
including dietary habits, can offer protection against the development of some types of cancer. Diet has the capacity to prevent oxidative damage induced in specific organs during chemotherapy, and antioxidant supplementation in the diet may be a possible adjuvant for cancer treatment or even prevent genomic injuries that may increase the predisposition to cancer.

Glutamine supplementation appears to have many beneficial effects. However, despite its chemopreventive ability demonstrated in this study, further studies are needed to confirm that glutamine is not associated with in the increased clastogenic damage observed using the micronucleus assay. It is still necessary to determine its mechanism of action (i.e., desmutagenic and/or bioantimutagenic) to allow nutritionists to develop the best method of administrating this amino acid. Glutamine can be used in DNA injury prevention or as an adjuvant in chemotherapy to reduce side effects, such as clastogenics.

\section{ACKNOWLEDGMENTS}

Research supported by Pró-Reitoria de Pesquisa e Pós-Graduação, Centro Universitário Filadélfia (UniFil), Fundação Araucária: Apoio ao Desenvolvimento Científico e Tecnológico do Paraná and Fundação de Apoio ao Desenvolvimento do Ensino, Ciência e Tecnologia of the State of Mato Grosso do Sul (FUNDECT). Renata Matuo was supported by grants from Coordenação de Aperfeiçoamento de Pessoal de Nível Superior (CAPES).

\section{REFERENCES}

Albertini SM and Ruiz MA (2001). O papel da glutamina na terapia nutricional do transplante de medula óssea. Rev. Bras. Hematol. Hemoter. 23: 41-47.

Angeli JPF, Ribeiro LR, Bellini MF and Mantovani MS (2006). Anti-clastogenic effect of beta-glucan extracted from barley towards chemically induced DNA damande in rodent cells. Hum. Exp. Toxicol. 25: 319-324.

Antunes LM and Bianchi ML (2004). Antioxidante da dieta como inibidores da nefrotoxicidade induzida pelo antitumoral cisplatina. Rev. Nutr. 17: 89-96.

Camargo JLV, Oliveira MLCS, Rocha NS and Ito N (1994). A detecção de substâncias cancerígenas em estudos experimentais. Rev. Bras. Cancerol. 40: 21-30.

Carvalho MM (2000). Imunologia, estresse, câncer e o programa Simonton de auto-ajuda. Psicol. USP 13: 27-30.

Diestel CF, Lopes-Paulo F, Marques RG and Horst NL (2005). Efeito da suplementação oral de L-glutamina na parede colônica de ratos submetidos à irradiação abdominal. Acta Cir. Bras. 20: 94-100.

Elsendoorn TJ, Weijl NI, Mithoe S, Zwinderman AH, et al. (2001). Chemotherapy-induced chromosomal damage in peripheral blood lymphocytes of cancer patients supplemented with antioxidants or placebo. Mutat. Res. 498: 145-158.

Flagg EW, Coates RJ and Greenberg RS (1995). Epidemiologic studies of antioxidants and cancer in humans. J. Am. Coll. Nutr. 14: 419-427.

Garófolo A, Avesani CM, Camargo KG and Barros ME (2004). Dieta e câncer: um enfoque epidemiológico. Rev. Nutr. 17: 491-505.

Gold LS, Slone TH and Bruce NA (1997). Food Chemical Risk Analysis. In: Prioritization of Possible Carcinogenic Hazards in Food (Tennant DR, ed.). Chapman and Hall, New York, 267-295.

Hayashi M, Morita T, Kodama Y and Sofuni T (1990). The micronucleus assay with mouse peripheral blood reticulocytes using acridine orange-coated slides. Mutat. Res. 245: 245-249.

Kada T, Inoue T and Namiki N (1982). Environmental Mutagenesis and Plant Biology. In: Environmental Desmutagens and Antidesmutagens (Klekowski EJ, ed.). Praeger, New York, 137-151.

Kada T and Shimoi K (1987). Desmutagens and bio-antimutagens-their modes of action. Bioessays 7: 113-116.

Kelloff GJ, Crowell JA, Steele VE, Lubet RA, et al. (1999). Progress in cancer chemoprevention. Ann. N. Y. Acad. Sci. 889: 1-13.

Kobayashi H, Sugiyama C, Morikawa Y, Hayashi M, et al. (1995). A comparison between manual microscopic analysis and computerized image analysis in the single cell gel electrophoresis assa. MMS Comm. 2: 103-115.

Krause MV and Mahan LK (2005). Alimentos, Nutrição e Dietoterápica. 11th edn. Editora Roca, São Paulo. 
Loeb LA, Springgate CF and Battula N (1974). Errors in DNA replication as a basis of malignant changes. Cancer Res. 34: 2311-2321.

Maxwell SR (1995). Prospects for the use of antioxidant therapies. Drugs 49: 345-361.

Mora LO, Antunes LM, Francescato HD and Bianchi ML (2003). The effects of oral glutamine on cisplatin-induced nephrotoxicity in rats. Pharmacol. Res. 47: 517-522.

Neu J, Roig JC, Meetze WH, Veerman M, et al. (1997). Enteral glutamine supplementation for very low birth weight infants decreases morbidity. J. Pediatr. 131: 691-699.

Ojopi EPB and Neto ED (2002). Genes e câncer. Biotecnol. Ciência Desenvol. 27: 28-37.

Oliveira RJ, Ribeiro LR, da Silva AF, Matuo R, et al. (2006). Evaluation of antimutagenic activity and mechanisms of action of beta-glucan from barley, in CHO-k1 and HTC cell lines using the micronucleus test. Toxicol. In Vitro 20: 1225-1233.

Oliveira RJ, Matuo R, da Silva AF, Matiazi HJ, et al. (2007). Protective effect of beta-glucan extracted from Saccharomyces cerevisiae, against DNA damage and cytotoxicity in wild-type (k1) and repair-deficient (xrs5) CHO cells. Toxicol. In Vitro 21: 41-52.

Oliveira RJ, Salles MJ, da Silva AF, Kanno TY, et al. (2009). Effects of the polysaccharide beta-glucan on clastogenicity and teratogenicity caused by acute exposure to cyclophosphamide in mice. Regul. Toxicol. Pharmacol. 53: 164-173.

Oliveira RJ, Sassaki ES, Monreal AC, Monreal MT, et al. (2013). Pre-treatment with glutamine reduces genetic damage due to cancer treatment with cisplatin. Genet. Mol. Res. 12: 6040-6051.

Pacífico SL, Leite HP and Carvalho WB (2004). O papel dos alimentos funcionais na prevenção e controle do câncer de mama. Rev. Bras. Cancerol. 50: 250-261.

Padilha PC and Pinheiro RL (2005). A suplementação de gluatamina é benéfica em doenças graves? Rev. Nutr. 18: 95-104.

Peres WAF, Paula T, Silva RARN and Coelho HSM (2003). A atuação da vitamina A e carotenóides e hepatocarcinogênese. Rev. Bras. Cancerol. 49: 113-120.

Potter JD and Steinmetz K (1996). Vegetables, fruit and phytoestrogens as preventive agents. IARC Sci. Publ. 61-90.

Ribeiro LR, Salvadori DMF and Marques EK (2003). Mutagênese Ambiental. In: Teste do Cometa para Detecção de Dano no DNA e Reparo em Células Individualizadas (Gontijo AMMC and Tice R, eds.). Editora ULBRA, Canoas, 247-279.

Sies H (1993). Strategies of antioxidant defense. Eur. J. Biochem. 215: 213-219.

Singh NP, McCoy MT, Tice RR and Schneider EL (1988). A simple technique for quantitation of low levels of DNA damage in individual cells. Exp. Cell Res. 175: 184-191.

Tice RR, Agurell E, Anderson D, Burlinson B, et al. (2000). Single cell gel/comet assay: guidelines for in vitro and in vivo genetic toxicology testing. Environ. Mol. Mutagen. 35: 206-221.

Waitzberg DL (2000). Nutrição Oral, Enteral e Parenteral na Prática Clínica. In: Câncer (Waitzberg DL, ed.). Atheneu, São Paulo, 1381-1393.

Waters MD, Brady AL, Stack HF and Brockman HE (1990). Antimutagenicity profiles for some model compounds. Mutat. Res. 238: 57-85.

Wattenberg LW (1992). Inhibition of carcinogenesis by minor dietary constituents. Cancer Res. 52: 2085s-2091s.

Weijl NI, Hopman GD, Wipkink-Bakker A, Lentjes EG, et al. (1998). Cisplatin combination chemotherapy induces a fall in plasma antioxidants of cancer patients. Ann. Oncol. 9: 1331-1337.

Ziegler RG, Brinton LA, Hamman RF, Lehman HF, et al. (1990). Diet and the risk of invasive cervical cancer among white women in the United States. Am. J. Epidemiol. 132: 432-445.

Ziegler RG, Subar AF, Craft NE, Ursin G, et al. (1992). Does beta-carotene explain why reduced cancer risk is associated with vegetable and fruit intake? Cancer Res. 52: 2060s-2066s. 